\title{
Weed Management Practices in Machine Transplanted Rice Cultivation
}

\author{
R.M.U.S.Bandara ${ }^{1}$, B. Marambe ${ }^{1}$, A.S.K. Abeysekara, W.M.U.B. Wickrama, \\ H.M.M.K.K.H. Dissanayaka, A.N. Siriwardana, \\ N.M.D.P. Nawarathna and Y.M.S.H.I.U. DE Silva
}

\author{
Postgraduate Institute of Agriculture \\ University of Peradeniya \\ Sri Lanka
}

\begin{abstract}
The yield performance of lowland rice varieties depends on the method of crop establishment. However, yield of transplanted rice is generally believed to be higher than that of dry-seeded rice. Broadcasting is the most widely practiced establishment method by Sri Lankan paddy farmers. Though it is easier to be practised it has several disadvantages such as high weed infestation, high insect pest infestation and lodging. Under the Yaya 11 program, farmers were introduced machine transplanting by Department of Agriculture. Inter row spacing of the transplanting machine is a fixed value of $30 \mathrm{~cm}$. It allows a severe weed infestation in the field and finally results a remarkable yield loss. Weed management is an essential practice in machine transplanting. Farmers are looking for a better weed management practice in machine transplanting. This study was conducted with the objective of finding out a better weed management practice in machine transplanting. A farmer's field demonstration experiment was conducted at Manapaha in Kurunegala district in Maha 2015/2016. The demonstration was to test 07 treatments namelyT1=Pretilachlor $300 \mathrm{~g} / \mathrm{l}+$ Pyribenzoxim $20 \mathrm{~g} / \mathrm{l}$ followed by Weedering twice, $T 2=$ Pretilachlor $300 \mathrm{~g} / \mathrm{l}$ + Pyribenzoxim 20g/l, T3= Pretilachlor $300 \mathrm{~g} / \mathrm{l}$ EC, T4= Pretilachlor $300 \mathrm{~g} / \mathrm{l}$ EC followed by Weedering twice, T5=Weedering twice (at 2 WATP and 4WATP), T6=Hand-weeding and T7=No-weeding. All treatments ultimately gave a significantly higher yields than no-weeded control. It is clear that weed control is essential in machine transplanted rice cultivation. Pretilachlor $300 \mathrm{~g} / \mathrm{l}$ EC was well performed among all herbicide treatments in machine transplanted rice cultivation.
\end{abstract}

Keywords: Machine Transplanting, Herbicide, Weedering

\section{INTRODUCTION:}

The yield performance of lowland rice varieties depends on the method of crop establishment. However, yield of transplanted rice is generally believed to be higher than that of dry-seeded rice (Balasubramanian et al., 2003). Broadcasting is the most widely practiced establishment method by Sri Lankan paddy farmers. Though it is easier to be practised it has several disadvantages such high weed infestation, high insect pest infestation and lodging. Under the Yaya 11 program farmers were introduced machine transplanting by the Department of Agriculture. Inter row spacing of the transplanting machine is a fixed value of $30 \mathrm{~cm}$. It allows a severe weed infestation in the field and finally resulting a significant yield

1 Department of Crop Science, Faculty of Agriculture, University of Peradeniya, Sir Lanka 
loss. Thus, weed management is an essential practice in machine transplanting. Farmers are looking for a better weed management options in machine transplanting. This study was conducted with the objective of finding a better weed management practice in machine transplanting.

\section{MATERIALS AND METHODS:}

An experiment was conducted at in a farmer's field at Manapaha in Kurunegala district in Maha 2015/2016 in order to evaluate and demostrate performances of different weed management practices in machine transplanted rice cultivation. The demonstration conducted to test 07 treatments namely $\mathrm{T} 1=$ Pretilachlor $300 \mathrm{~g} / 1+$ Pyribenzoxim $20 \mathrm{~g} / 1$ followed by Weedering twice, T2= Pretilachlor 300g/l +Pyribenzoxim 20g/l, T3= Pretilachlor 300g/l EC, T4= Pretilachlor $300 \mathrm{~g} / 1 \mathrm{EC}$ followed by Weedering twice, T5=Weedering twice (at 2 WATP and 4WATP), T6=Hand-weeding and T7=No-weeding.

Each Treatment plot was 18 square meters in size. Crop establishment was done using machine-transplanter. Fertilizer application was done according to the recommendation of the Department of Agriculture. Treatment plots were not replicated because in a farmer's field experiment replicated blocks are difficult to be practiced and assumed that there was no considerable variation in a well levelled paddy field. Weed dry weights were taken in each treatment using 03 quadrates at 06 weeks after transplanting in such a way that data could be analysed as three replicates. Final grain yields were measured in 03 crop cuts in each plot in such a way that data could be analysed as three replicates. Data was analysed employing ANOVA in a RCB Design using SAS software.

\section{RESULTS AND DISCUSSION:}

\begin{tabular}{lccc}
\hline \multicolumn{1}{c}{ Treatmet } & $\begin{array}{c}\text { Weed Dry } \\
\text { Weight } \\
\left(\mathbf{g} / \mathbf{m}^{\mathbf{2}}\right)\end{array}$ & $\begin{array}{c}\text { WCE } \\
\mathbf{\%}\end{array}$ & $\begin{array}{c}\text { Grain } \\
\text { Yield } \\
\mathbf{( m t / h a )}\end{array}$ \\
\hline $\begin{array}{l}\text { Pretilachlor 300g/l +Pyribenzoxim 20g/l } \\
\text { followed by Weedering twice }\end{array}$ & $1.63 \mathrm{c}$ & 98.5 & $6.63 \mathrm{~b}$ \\
Pretilachlor 300g/l +Pyribenzoxim 20g/l & $1.50 \mathrm{c}$ & 98.7 & $6.70 \mathrm{~b}$ \\
Pretilachlor 300g/l EC & $1.43 \mathrm{c}$ & 98.7 & $7.84 \mathrm{a}$ \\
Pretilachlor 300g/l EC & $1.50 \mathrm{c}$ & 98.7 & $6.63 \mathrm{~b}$ \\
followed by Weedering twice & & & \\
Weedering twice (at 2 WATP and 4WATP) & $33.96 \mathrm{~b}$ & 69.8 & $6.63 \mathrm{~b}$ \\
Hand-weeding (Control) & $0 \mathrm{c}$ & 100.0 & $6.85 \mathrm{a}$ \\
No-weeding (Control) & $112.38 \mathrm{a}$ & --- & $3.50 \mathrm{c}$ \\
\hline ** Means with the same letter are not significantly different $(\alpha=0.05)$. &
\end{tabular}

Table 1. Weed dry weight, Weed Control Efficacy, Plant height and Grain yield of different treatments

Weed dry weights of all treatments were significantly different from no-weeded control. Weed dry weights of all herbicide treatments were comparable with Hand-weeded control. Weed dry weights of Weedering twice was significantly different from no-weeded control. Herbicide treatments showed a lower weed dry weight than Weedering twice treatment. It is 
because herbicide treatments could kill weeds emerged only from inter rows and within rows whereas weedering could only kill weeds emerged from inter rows. Weedering could enhances the growth of weeds which are vegetatively propagated through stem cuttings and that's why weedering twice treatment showed a higher weed dry weight than that of herbicide treatments. Pretilachlor $300 \mathrm{~g} / \mathrm{l}$ EC and hand-weeded control showed comparable grain yields. Yields of Pretilachlor $300 \mathrm{~g} / \mathrm{l} E C$ and hand-weeded control were the highest among all. Only weedering treatment though it showed a higher weed dry weight its yield was comparable with treatments $T 1, T 2$ and $T 3$ because it was still capable of managing weed population below the economic threshold. Though weedering loosen and aerate the soil, there was no yield increment in that treatment as the rice crop is well adapted to submerged condition and thus no any special response for loosening and aeration of the soil by weedering practice.

\section{CONCLUSION:}

All treatments ultimately gave a significantly higher yields than no-weeded control. It is clear that weed control is essential in machine transplanted rice cultivation. Only Weedering was effective in managing weed population below the economic threshold in machine transplanted rice cultivation. Pretilachlor $300 \mathrm{~g} / \mathrm{l}$ EC performed well among all herbicide treatments in machine transplanted rice cultivation.

\section{REFERENCES:}

Abeysekera, A.S.K.,K.Jayawardana, L.Ranasingha and A Senevirathna (2000). Effect of novel herbicides on control of weeds in rice fields in Sri Lanka. Proc of the Third International weed science Congress, Fozdo, Igussu, Brazil pp249-251

Abeysekera, A.S.K.,Jhonson D, Herath H.M.S and U.B. Wicrama(2006) Diversity of Weed Flora in Wet Seeded Rice in Sri Lanka. International Rice Congress 2006. New Dilhe India $9^{\text {th }}-13^{\text {th }}$ October 2006.

Balasubramanian, V., J.K. Ladha, R.K. Gupta, R.K. Naresh, R.S. Mehla, B. Singh and Y. Singh. (2003). Technology options for rice in the rice-wheat system in south Asia. In: Improving the Productivity and Sustainability of Rice-Wheat Systems: Issues and Impacts. ASA Special publication 65 .

Balasubramanian V., R. Rajendra, V. Ravi, N. Chellaiah, E. Castro, B. Chandrasekaran, T. Jayraj and S. Ramanathan. 2006. Integrated Crop Management for Enhancing Yield in Transplanted Rice Systems in Kerala. International Symposium on Rice from Green Revolution to Gene Revolution. Directorate of Rice Research, Hyderabad, India, 4-6 October 2004.

Department of Agriculture, Sri Lanka, Pest Management Recommendations (2015) 